\title{
The Development of English Conversation Training Course for Front Office Staff: A Case Study of Baiyok Hotel, Bangkok, Thailand
}

\author{
Nongyao Bousri \\ Department of Business English, Faculty of Liberal Arts, North Bangkok University, Pathumthani, Thailand
}

Email address:

nongyao.bo@northbkk.ac.th

To cite this article:

Nongyao Bousri. The Development of English Conversation Training Course for Front Office Staff: A Case Study of Baiyok Hotel, Bangkok, Thailand. Social Sciences. Vol. 7, No. 1, 2018, pp. 22-28. doi: 10.11648/j.ss.20180701.14

Received: August 23, 2017; Accepted: September 27, 2017; Published: December 142017

\begin{abstract}
The purpose of research were to analyze the current working situation (after training) of English conversational skills (listening and speaking) for front office staff of Baiyok Hotel and to develop training course to achieve $70 \%$ up effectiveness criteria. In addition, need to survey the front office staff's satisfaction toward the training course. The sample, was selected by a group of experimental research, was 15 front office staff of Baiyok Hotel, Bangkok, Thailand. The study was conducted by questionnaires. The paired-sample t-test and effect-size were used to analyze the data in order to assess the staff's ability before and after attending the training program. Mean and standard deviation of items were used to evaluate the front office staff's conversation and satisfactions toward the training program. The results of the study were found after the course implementation, the front office staff gained higher scores at the significant level of .05, it showed that the content was useful and it can help the staff improve their skills. The next result showed that the staff's listening ability to customers' order/requests (4.03) as the most usage during their work and the staff's speaking ability to customers as the highest usage included English in different social occasions (3.94). The latest result of the most staff's satisfaction was the highest level in teaching \& learning methodology (4.53).
\end{abstract}

Keywords: English Conversation Skill, Hotel Front Office Staff, Training Course, Satisfaction

\section{Introduction}

In today's world, the importance of English cannot be denied and ignored since English is the most common language spoken everywhere. With the help of developing technology, English has been playing a major role in many sectors especially service industry such as hotel management. Thai people know that English being a universal language is among businesses. As Thailand being a developing country, if Thais are able to communicate clearly is a key to success.

English is the most commonly used language around the world. So, it is really important for us to learn it. At hotel, all staff value English learning; the researcher needs to help all staff to enhance their English communication skills. At Baiyok Hotel Bangkok, English is a MUST for all staff as it is considered to be the most useful and effective tool to communicate with customers. So, the hotel always invests time and money in improving conversational skills for its staff.

Every hotel has a front office, and which the reception in a hotel is the front office. Front office is the first place where guests/customers arrive and come in touch with the staff. Front office is the mirror of a hotel. The function of the front office is to directly get in touch with customers. The front office can discover more information about the customer by asking the customer questions and give answer ask by guest/customer also helping the customers out. Employees working in the front office will also help customers about problems and complaints. The front office in the hotel industry, also called the reception area, which the receptionist is the one who get in touch with the customers, most importantly, confirm their reservation and answering their questions. The employees who work in the lobby of the hotel are also part of the front office as the employees get in touch with customers directly. The employees will show customers the way and carry the luggage for customers. There are 
different parts in the front office of a hotel, which included reception, providing services when customers asked, mailing information, concierge and employees who manage with money (cashier).

The motivation of the front office staff might be low as they are doing repeated work and usually their pays are the lowest compared to other staff in other departments. This is a very important issue as these staff members will get in touch with customers the most and this might affect the profitability and efficiency of the company. The staff members might have high levels of stress as the staff might always meet bad-tempered customers and the staff might get a lot of complaints, making this hard for front office staff members to maintain their good services. The staff faces many challenges and stress due to stubborn customers. [1]

The study of impact of training and development on organizational performance related to employee will help organization to understand the advantages of training are much more than its disadvantages. [2] Therefore, the researcher needs to study how to get a solution to develop of skills and continuous training that should be provided to front office staff, as this will improve their services to provide for customers.

\section{Objectives}

The training course is a process of developing knowledge and skills of learners to success in their job. In order to prepare the training program there are many steps to do such as identifying the training needs, preparing the trainer and trainee, creating the training course, explaining the operations, and following up the course effectiveness by evaluation. The front office staff's preliminary test in training course development was used as a guideline for trainer's course. The need survey was used for investigating learners' needs and the purposes for the design of training course. For purpose of study, first to analyze the current working situation (after training) of English conversational skills (listening and speaking) for front office staff of Baiyok Hotel and then to develop training course to achieve $70 \%$ up effectiveness criteria. After that to survey the front office staff's satisfaction toward the training course

\section{Research Questions}

This study examines how to develop English conversation training course, identifying the views of both the front office staff's skill and satisfaction. The research questions (RQs) follow:

RQ1. According to the front office staff's English conversation skill, how can the researcher use to improve the training strategy effectively?

RQ2. What types of the front office staff's satisfaction for training course do the staff feel is useful?

\section{Sample}

The sample group of experimental research was 15 front office staff of Baiyok Hotel, Bangkok, Thailand.

\section{Methodology}

This study has been designed as an experimental research and development study. It aims to develop a training course for front office staff's English conversation skill by inspection to the front office staff's working in the present situation first. The researcher will use method of independent pre-test and post-test on one group of the staff in order to check their background knowledge and to see the progress of the scores after the training course. The researcher can check their perception and the course effectiveness by comparing their scores between pre-test and post-test. The result from the study is then using develop their English conversation skills.

The implementation of the training program was established within the sample group of 15 hotel front office staff at the Baiyok Hotel. The Tuckman's experimental type [3] was used as the experimental method for the training program as in the following figure.

Research Design:

Table 1. Type of experiment.

\begin{tabular}{llll}
\hline Group & Pretest: Before the training program & Front office staff's training program & Posttest: After the training program \\
\hline Experiment group & $\mathrm{T} 1$ & $\mathrm{X}(15)$ & $\mathrm{T} 2$ \\
\hline
\end{tabular}

Source: The Tuckman's experimental type

\section{Data Collection}

Data collection started during October, 2015. The researcher collected data from the participants by conducting semi-structured interview and trying out with pilot group. Then, hand out the questionnaires.

\subsection{Questionnaires}

The copies of questionnaire were distributed to 15 hotel office staff who is working at the Baiyok hotel. All copies of the questionnaire were collected by the researcher to analyze.
The findings were employed as the data to develop English listening and speaking training course and to survey the satisfaction of the participants.

\subsection{Implementation of the Training Course}

An orientation training course was implemented with 15 hotel office staff who is working at the Baiyok hotel. It was designed as a short training course for one month (45 hours).

\subsection{Test}

The English proficiency test on listening and speaking 
skills were developed to use for pre-test and post-test. The tests were distributed to 15 hotel front office staff before and after the implementation of the training course. Then the researcher would analyze to check the difference of their scores and evaluate quality of the training course.

\section{Research Instruments}

\subsection{The Questionnaire with Some Open-Ended Questions for the 3 Parts}

Part 1 comprises 6 checklist items about general information of the respondents such as genders, level of English listening proficiency, level of English speaking proficiency, experience in using English, and duration of English training course appropriate for them.

Part 2 comprises 2 main parts of 9 items to survey the language function in listening and speaking that the front staff often uses. The respondents were asked to rate their opinions based on five point Likert scales.

Part 3 comprises 10 items concerning about survey the satisfaction of the participants. The respondents were asked to rate their opinions based on five point Likert scales.

\subsection{The 9 Units Hotel English Textbook and Course Materials Which Were Developed Based on Authentic Materials Used in the Hotel Industries [4]}

Table 2. Hotel role-play of front desk.

\begin{tabular}{|c|c|c|c|c|c|}
\hline Name & Room Size & Number of People & Number of Nights & Wake-up Call $(\mathbf{Y} / \mathbf{N})$ & Method of Payment \\
\hline
\end{tabular}

Ask the questions on the below side of this worksheet. Important Questions:
(1) How may I help you?
(2) Can I have your name please?
(3) How do you spell that?
(4) Would you like a single or a double?

(5) How many people are you traveling with?

(6) How many nights will you be staying?

(7) How will you be paying?

(8) Would you like a wake-up call?

(9) Is there anything else you would like to know? [5]

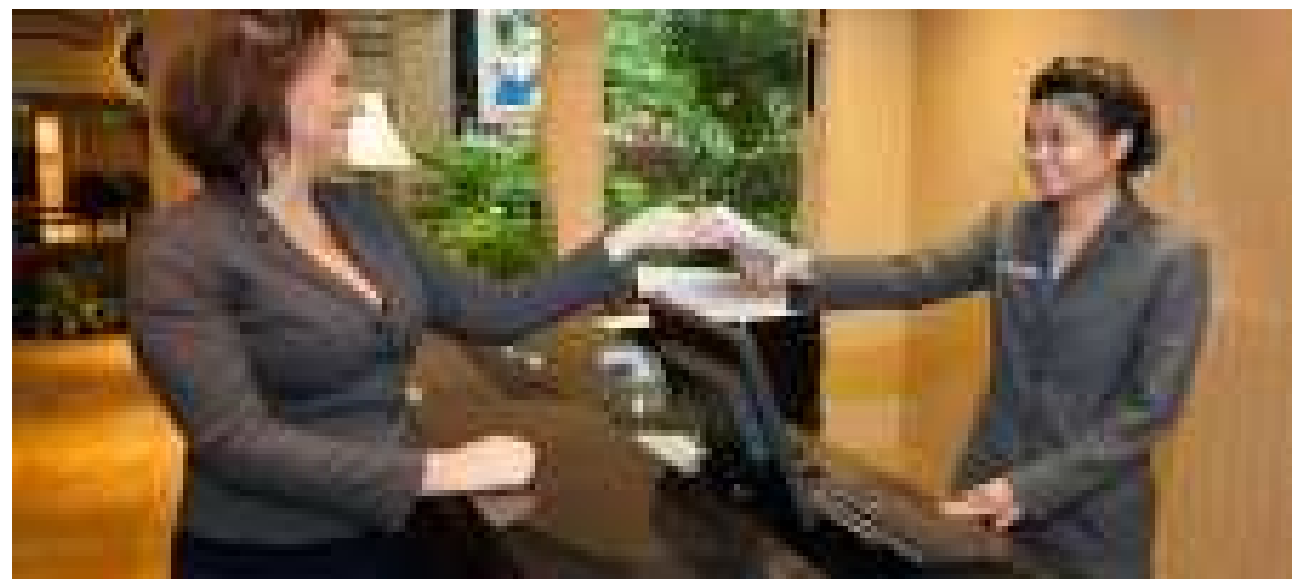

Figure 1. When the systems are down and a guest is trying to check in.

Table 3. Hotel English conversation lesson plan.

\begin{tabular}{|c|c|c|c|}
\hline Unit & Content & Language Function & Learning Activity \\
\hline 1. & $\begin{array}{l}\text { Unit 1: Hotel information } \\
\text { 1. Types of hotels } \\
\text { 2. Hotel organization structure } \\
\text { 3. Jobs in the hotel } \\
\text { 4. Types of bedrooms }\end{array}$ & $\begin{array}{l}\text { 1. Read the hotel information and answer the questions } \\
\text { 2. Lecture and discuss hotel organization structure, jobs } \\
\text { that can be found at a hotel and types of bedrooms }\end{array}$ & $\begin{array}{l}\text {-Reading; types of } \\
\text { Accommodations } \\
\text {-Practice and do exercises }\end{array}$ \\
\hline 2. & $\begin{array}{l}\text { Unit 2: Front Office } \\
\text { 1. General information about the Front Office } \\
\text { 2. Vocabularies and expressions } \\
\text { 3. Making a reservation and checking in } \\
\text { * Reading Quiz 1* }\end{array}$ & $\begin{array}{l}\text { 1. Lecture and discuss about The Front Office } \\
\text { 2. Grammar, vocabulary and expression used at the } \\
\text { Front Office } \\
\text { 3. The registration form }\end{array}$ & $\begin{array}{l}\text {-Listening and fill in the reservation } \\
\text { form } \\
\text {-Role Playing about room } \\
\text { reservation through the internet, e- } \\
\text { mail or telephone and checking in }\end{array}$ \\
\hline 3. & Unit 3: Front Office & 1. Read a story about the Front Office and answer the & - Listen to the dialogue and fill in \\
\hline
\end{tabular}




\begin{tabular}{|c|c|c|c|}
\hline Unit & Content & Language Function & Learning Activity \\
\hline \multirow{8}{*}{4.} & 1. Reading about the Front Office & questions & the registration form \\
\hline & 2. Checking out & 2. The Checkout form & \multirow{3}{*}{ - Role Playing about checking out } \\
\hline & 3. Understanding the hotel bills in general & \multirow[t]{2}{*}{3 Reading Quiz paper } & \\
\hline & 4. Questions and answers about the hotel bills & & \\
\hline & Unit 4: Food and Beverage & 1. Lecture and discuss about Food and Beverage & \multirow{4}{*}{$\begin{array}{l}\text { - Question Tag } \\
\text { - Short answers }\end{array}$} \\
\hline & 1. Vocabulary about Food and Beverage & 2. Discuss about the Menu & \\
\hline & $\begin{array}{l}\text { 2. The Menu } \\
\text { 3. Requests and Offers }\end{array}$ & 3. Lecture and discuss about grammar and vocabulary, & \\
\hline & *Vocabulary Quiz 1* & & \\
\hline \multirow[b]{2}{*}{5.} & $\begin{array}{l}\text { Unit 5: Food and Beverage } \\
\text { 1. Taking order and giving information about }\end{array}$ & $\begin{array}{l}\text { 1. Practice taking order and answering the requests in } \\
\text { the restaurant }\end{array}$ & \multirow[b]{2}{*}{-Spoken activity } \\
\hline & $\begin{array}{l}\text { Food and Beverage in a restaurant } \\
\text { 2. Taking order and giving information about } \\
\text { Food and Beverage (Room service) }\end{array}$ & $\begin{array}{l}\text { the restaurant } \\
\text { 2. Practice taking order and answering the requests for } \\
\text { Room service }\end{array}$ & \\
\hline \multirow{3}{*}{6.} & Unit 6: Problems and solutions & & \multirow{3}{*}{$\begin{array}{l}\text {-Spoken activity } \\
\text {-Watch a VDO of how to deal with } \\
\text { the problem }\end{array}$} \\
\hline & $\begin{array}{l}\text { 1. Understanding guests problems } \\
\text { 2. Dealing with problems }\end{array}$ & $\begin{array}{l}\text { 1. Lecture and discuss about problems guests might find } \\
\text { and solutions }\end{array}$ & \\
\hline & 3. Vocabulary and expressions & & \\
\hline 7. & $\begin{array}{l}\text { Unit 7: Places to visit and Giving Directions } \\
\text { 1. Prepositions of locations and directions } \\
\text { 2. Giving directions indoor } \\
\text { 3. Describing and recommending places to } \\
\text { visit }\end{array}$ & $\begin{array}{l}\text { 1. Lecture and discuss about prepositions of locations } \\
\text { and directions } \\
\text { 2. Vocabulary about interesting places to visit } \\
\text { 3. Practice giving directions conversations }\end{array}$ & -Spoken activity \\
\hline \multirow{4}{*}{8} & $\begin{array}{l}\text { Unit 8: Meeting and Conference Preparing } \\
\text { 1. Items of Conference Equipment }\end{array}$ & \multirow{4}{*}{ 1. Vocabulary about conference Equipments } & \multirow{4}{*}{$\begin{array}{l}\text {-Spoken activity } \\
\text {-Watch a VDO about seating } \\
\text { arrange-ments }\end{array}$} \\
\hline & 2. Plans of Seating Arrangements & & \\
\hline & 3. Describing size and dimensions & & \\
\hline & *Vocabulary Quiz 2* & & \\
\hline \multirow{4}{*}{9.} & $\begin{array}{l}\text { Unit } 9 \text { : Telephoning } \\
\text { 1. Taking a message by phone }\end{array}$ & \multirow{4}{*}{$\begin{array}{l}\text { 1. Taking and leaving a message expressions } \\
\text { 2. Lecture and discuss about taking and leaving a } \\
\text { message }\end{array}$} & \multirow{4}{*}{$\begin{array}{l}\text {-Spoken activity } \\
\text {-Watch a VDO } \\
\text {-Practice and do exercises }\end{array}$} \\
\hline & 2. Leaving a message at the information desk & & \\
\hline & 3. Sending someone up to a room & & \\
\hline & 4. Dealing with emergency & & \\
\hline
\end{tabular}

\subsection{The Pre-test and Post-test Papers}

The pretest-posttest comparative paper with experimentalcontrol group that is one of the quantitative researches has been used in the research. Pretest has been held in the research in order to ascertain whether the participated front office staff to whom the application is performed are equal or not, and posttest has been held with regards to display the effects of the achievement test which was evaluated after the training course. For pre and posttest paper would be questions which were written for each research objective. The question paper for pre-and post-test would contain multiple choices, true/false and short answers. The paper also was begun by writing at least 10 test items based on the research objectives. The difference between pre and posttest points is significant, and then success rate is higher in test group.

\section{Data Analysis}

The data obtained from the returned questionnaire and was analyzed using the Statistical Package for the Social Sciences (SPSS). In the first part of personal information, the researcher can use percentage and frequency count in analysis of answers from the questionnaire. The next step, the analysis on Arithmetic Mean ( $\overline{\mathrm{x}})$ and Standard Deviation Mean (S.D) were used to present the outcome of the front office staff's working after training course. In the meantime, the survey of the participated staff's satisfaction also was analyzed by Mean $(\bar{x})$ and S.D to organize scale and rank. In particular of the Tuckman's experimental type [3] was used as the experimental method of the pretest and posttest. Especially, the effectiveness of the training course was compared by the pretest and posttest.

\section{Findings}

\subsection{The Findings Obtained from the Analysis of the Language Function Results on the Current Working Situation Were Summarized as Follows}

\section{Language function in listening}

The results showed that the front office staff's listening ability to customers' order/requests (4.03) as the most usage during their work, followed by listening to customers' questions (4.00), and listening to figures e.g. telephone number, address (3.92). The results also showed that function with the least usage was listening to news or information (3.67), as shown in Table 4. 
Table 4. The use of language functions (9 units) in listening during their current work.

\begin{tabular}{|c|c|c|c|}
\hline & Function & Mean & S.D \\
\hline \multicolumn{4}{|c|}{ Listening } \\
\hline 1 & Listening to description/explanation & 3.73 & 0.648 \\
\hline 2 & Listening to news or information & 3.67 & 0.757 \\
\hline 3 & Listening to customers' questions & 4.00 & 0.797 \\
\hline 4 & Listening to figures e.g. telephone number, price and address & 3.92 & 0.848 \\
\hline 5 & Listening to suggestions / comments & 3.72 & 0.845 \\
\hline 6 & Listening to superiors' commands & 3.89 & 0.737 \\
\hline 8 & Listening to customers' orders / requests & 4.03 & 0.689 \\
\hline 9 & Listening to customers' complaints & 3.80 & 0.876 \\
\hline
\end{tabular}

Language function in speaking

For the use of speaking function, the results showed that the functions they reported high usage included English in different social occasions e.g. greeting, giving thanks and asking for information/ explanation/ description about services provided by front office (3.94). The second rank was informing figures e.g. price/expense (3.88), followed by giving direction (3.78), and the lowest speaking function was encouraging customers to buy product or to use service (3.58), as shown in Table 5.

Table 5. The use of language functions (9 units) in speaking during their work.

\begin{tabular}{|c|c|c|c|}
\hline & Function & Mean & S.D \\
\hline \multicolumn{4}{|c|}{ Speaking } \\
\hline 1 & Giving and asking for information / explanation / description about services provided by front office & 3.94 & 0.889 \\
\hline 2 & Informing figures e.g. price / expense & 3.88 & 0.826 \\
\hline 3 & Telephoning & 3.66 & 0.946 \\
\hline 4 & Introducing product / service & 3.72 & 0.863 \\
\hline 5 & Giving direction & 3.78 & 0.934 \\
\hline 6 & Encouraging customers to buy product or to use service & 3.58 & 0.922 \\
\hline 8 & Contacting with colleagues and superiors & 3.67 & 0.856 \\
\hline 9 & Using English in different social occasions e.g. greeting, giving thanks & 3.94 & 0.941 \\
\hline
\end{tabular}

\subsection{The Findings Obtained from the Analysis of the Difference of the Front Office Staff's Scores and Evaluate Quality of the Pre and Post Training Course}

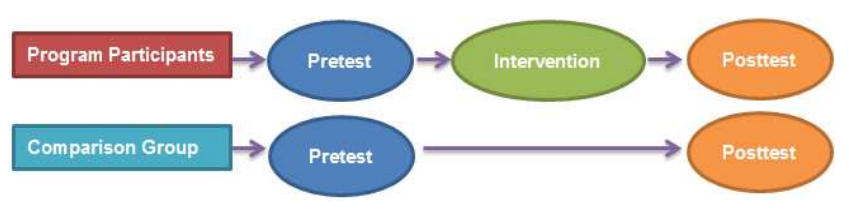

Figure 2. Pretest-Posttest only one way design.

Table 6. Mean, S.D., and T-test.

\begin{tabular}{lllllll}
\hline Test & To-tal score & Mean & S.D. & t & df & Sig. \\
\hline Pre-test & 55 & 26.46 & 5.64 & -4.97 & 49 & .000 \\
Post-test & 55 & 30.68 & 7.37 & & & \\
\hline
\end{tabular}

*sig.05

From the table 6, after the implementation course, the staff gained higher scores at the statistically significant.05 level.

The success of the training course, according to the staff scores, can be clearly shown in their higher scores. In other words, this can be said that the front staff gained more hotel English conversation knowledge and skills from the training course.

The results showed that the content was useful and could help the staff improve their skills. Therefore training was the process of developing skills in order to more effectively perform a specific job or task. [6]
However, this finding can be concluded that the method and content used in the orientation English training course meets the staff's demands and will be useful to train the staff in the field of hotel.

\subsection{The Findings Obtained from the Survey of the Participants' Satisfaction Toward the Hotel English Conversation Training Program}

Table 7. Mean and S.D. of their satisfaction.

\begin{tabular}{llll}
\hline Item & Topic & Mean & S.D. \\
\hline 1. & Contents & 4.43 & 0.68 \\
2. & Language Functions & 4.48 & 0.53 \\
3. & Teaching\& Learning methodology & 4.53 & 0.38 \\
4. & Evaluation & 4.08 & 0.64 \\
5. & Course materials & 4.34 & 0.44 \\
6. & Instructor & 4.40 & 0.48 \\
& Total & 4.37 & 0.53 \\
\hline
\end{tabular}

The success of the program according to the front office staff's opinions was clearly stated in table 7 that the participants had positive high satisfaction in the appropriateness of teaching and learning methodology of language training course (4.53), language function (4.48), contents (4.43), instructor (4.40), course materials (4.34) and evaluation (4.08). The participants felt that they gained more English knowledge and skills from the training program. The overall success of the training program was also at a high level with total mean of 4.37 . 


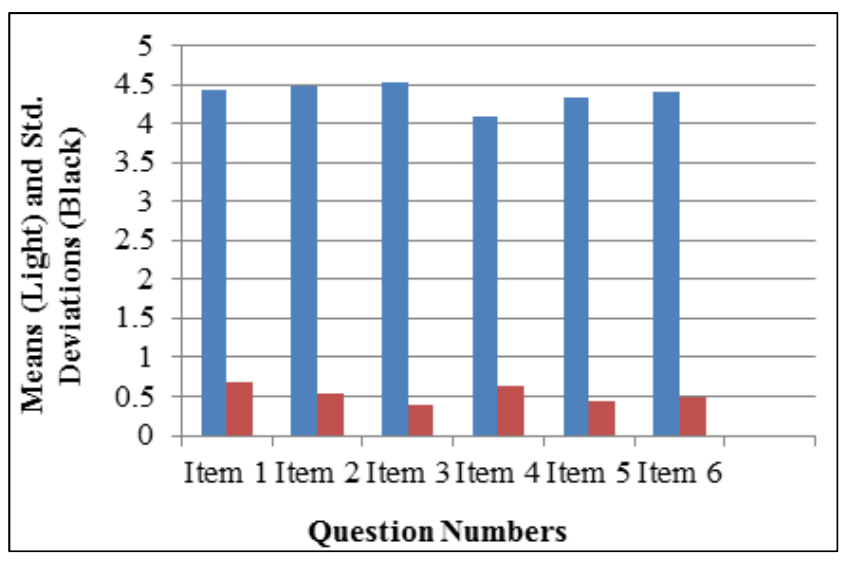

Figure 3. The participants' satisfaction on training course.

\section{Discussion and Conclusion}

\subsection{Discussion of the Findings}

The study is qualitative research that finds out how to improve their working ability of the front office staff with their English conversation skill. The researcher is interested in surveying this because there are the front office staffs who are alumni of the researcher to work at Baiyok Hotel, Bangkok. Thus the study was more comfortable for the research to get in touch them easily through the hotel.

The present study has addressed the following research questions:

RQ1. According to the front office staff's English conversation skill, how can the researcher use to improve the training strategy effectively?

From result of using pre-test with the front office staff, the researcher could know their problem with their English conversation in working by the researcher's observation, and their scores. Therefore, the training course was conducted by improving their hotel English conversation to follow the criteria $70 \%$ up. After the English curriculum on a short course was trained as well, the research could measure their scores and compare the result with pre-test. The study was found that the front office staff gained more hotel English conversation knowledge and skills from the training course. The success of the training course, according to the implementation course, the staff gained higher scores at the statistically significant.05 level, could be clearly shown in their higher scores which can be shown in table 6 .

The results showed that the content was useful and could help the staff improve their skills. Thus, training was the process of developing skills in order to more effectively perform a specific job or task. [6] The results was also found the most staff reported the function the staff always use in listening skill which included listening to customers' orders and requests, followed by listening to questions. The staff required their listening skill training course to be a listening for communication with foreign customers which could be shown in table 4. However, the listening skill could not be separated from speaking because the listening skill was a two-way communication. People cannot talk without listeners. Therefore, communication requires both listening and speaking. This is undeniable that effective communication needs speaking and listening class.

Moreover, the front office staff has to communicate with foreign tourists every day, as the front staff is the first group of people to meet the customers. Therefore, the speaking is production in the oral mode to send an oral message: thus, this is the most direct method of communication. [8] The front office staff needs to use speaking skill in order to respond to the customers, solve the problem, give information, offer assistance, or even engage in conversation over the phone. However, the study was obvious that the front office staff should have the most speaking skill for their communication skill at work. Their ability on speaking skill could be clearly shown in their higher scores.

RQ2. What types of the front office staff's satisfaction for training course do the staff feel is useful?

The results showed that most staff's satisfaction was the highest level in teaching\& learning methodology (4.53), as shown in Table 7. Recent research literature suggests that while many factors contribute to achieving these goals, what trainers know and are able to do is one of the most important factors influencing trainees' learning. [9] Moreover, the total mean was reported from the hotel front office staff (4.37) that was the highest level. The study was shown to the overall success of the training program to the participants' satisfaction.

In addition, the participants' satisfaction is an important indicator of the quality of learning experiences, and learnerinstructor interaction is significant predictors of student satisfaction. [10]

\subsection{Conclusion}

The following conclusions can be drawn from the discussion above.

RQ1. The study was found that the front office staff gained more hotel English conversation knowledge and skills from the training course. The staff gained higher scores at the significant.05 level, could be clearly succeeded of the training course. In addition, the staff also preferred the training course using bilingual languages, which were Thai and English, to build the staff's self-confident regarding customers' cross culture. This could encourage and help to understand English conversation situations with diverse language and cultural backgrounds.

The success of the development of this training program was from the appropriate studies toward the front staff, and the program evaluation of using 9 units English textbook which helped identify the fine contents and communication skills for the training program materials. These training courses also provided realistic information for the development of the front staff which was suitable to the reallife situations in hotels and meet their requirement.

In addition, all organizations should provide training their employees. The employees already have discussed that training and development have advantages not only for employees but the ultimate benefit is for the organization 
itself. If the performances of the employees are not good it will affect the whole organization. [2]

RQ2. The most staff's satisfaction had the highest positive in the appropriateness of teaching and learning methodology of the language training course.

The achievement of development of this training course was from the appropriate study analysis toward the hotel front staff. Also, the teaching and learning activities should help the front staff to become more competent in both English communication skills and knowledge of hotel contents. Therefore, the course should be consisted of language knowledge and skill and meet the requirement of the front staff. [11]

Besides the front staff's suggestion, the staff required more time to practice their hotel English communication skills, and the staff felt that one month, 45 hours of training was not enough for them. The duration of the training program should be appropriately planned for two months, 90 hours instead of one month, 45 hours.

Regarding further paper, the researcher prefers to study more the staff conversation problem with the hotel quests to gain depth information. However, the role of basic training of technology to the front staff is also interesting, specifically for check-in and check-out, assessing whether automated booths are an option for business-driven hotels and the perceptions of such technology by customers. Due to technology is a clear current and future theme and needed to be at the forefront of delivering customer service.

\section{Acknowledgements}

This study is supported by Science Publishing Group Fund. Thanks to my beloved family for powerful inspiration throughout my life.

\section{References}

[1] C. Mitchell, 2003-2016, e-book, Wikipedia.
[2] Raja A. G. Khan, Furqan A. Khan \& Dr. Muhammad A. Khan, (2011). Impact of Training and Development on Organizational Performance, University of Lahore, Pakistan.

[3] Tuckman, B. (1975), Measuring Educational Outcomes: Fundamentals of Testing, New York: Harcourt Bruce Javanovich.

[4] Hotel English conversation, lesson plan and course syllabus (2016), North Bangkok University, Thailand.

[5] Mercy 29089220, 2014. Mixed up conversation: at the front desk of a hotel.

[6] Beebe, A. Steven, Mottet, P. Timothy, Roach, K. David, (2004) Training and Development: Enhancing Communication and Leadership skills, West (Reno, NV, U.S.A.)

[7] McGrath, S. (2008). What qualities you need to succeed?: Retrieved from travel industry careers.

[8] Hair, D., Friedrich, G. W., \& Dixon, 1. D. (2005). Strategiccommunication in business and the professional, New York: Houghton Mifflin.

[9] Darling-Hammond, L. \& Sykes, G. (Eds.) (1999). Teaching as the Learning Profession, San Francisco: Jossey-Bass; Fullan, M., Hill, P., \& Crevola, C. (2006). Breakthrough, Corwin Press; Wilson, S. M., Floden, R. E., Ferrini-Mundy, J. (2001). Teacher Preparation Research: Current Knowledge, Gaps, and Recommendations, A Research Report Prepared for the U.S., Department of Education, Seattle, WA: Center for the Study of Teaching and Policy. (February).

[10] Moore, M. G., \& Kearsley, G. (1996) Distance education: A systems view. New York, NY: Wadsworth; Yukselturk, E., \& Yildirim, Z. (2008). Investigation of interaction, course structure and flexibility as the contributing factors to students' satisfaction in an online certificate program. Educational Technology \& Society, 11(4), 51-65.

[11] Tassanee Taraporn, Sa-ngaim \& Bamrung Torat, 2014, The Development of Hotel English Training Program Focusing on Task-based Instruction to Enhance Communication Skills, Ph.D in Curriculum and Instruction, Silapakorn University, Thailand. 